\title{
Evaluation, management and prevention of lower extremity youth ice hockey injuries
}

This article was published in the following Dove Press journal:

Open Access Journal of Sports Medicine

21 November 2016

Number of times this article has been viewed

\author{
Charles A Popkin' \\ Brian M Schulz ${ }^{2}$ \\ Caroline N Park' \\ Thomas S Bottiglieri' \\ T Sean Lynch' \\ 'Department of Orthopedic Surgery, \\ Center for Shoulder, Elbow and \\ Sports Medicine at Columbia \\ University, New York, NY, ${ }^{2}$ Kerlan-Jobe \\ Orthopedic Clinic, Los Angeles, \\ CA, USA
}

Correspondence: Charles A Popkin Department of Orthopedic Surgery, Center for Shoulder, Elbow and Sports Medicine at Columbia University, 622 West I68th Street, New York, NY 10032, USA

Tel + I 2123054787

Fax +l 2123059754

Email cp2654@columbia.edu

\begin{abstract}
Ice hockey is a fast-paced sport played by increasing numbers of children and adolescents in North America and around the world. Requiring a unique blend of skill, finesse, power and teamwork, ice hockey can become a lifelong recreational activity. Despite the rising popularity of the sport, there is ongoing concern about the high frequency of musculoskeletal injury associated with participation in ice hockey. Injury rates in ice hockey are among the highest in all competitive sports. Numerous research studies have been implemented to better understand the risks of injury. As a result, rule changes were adopted by the USA Hockey and Hockey Canada to raise the minimum age at which body checking is permitted to 13-14 years (Bantam level) from 11-12 years (Pee Wee). Continuing the education of coaches, parents and players on rules of safe play, and emphasizing the standards for proper equipment use are other strategies being implemented to make the game safer to play. The objective of this article was to review the evaluation, management and prevention of common lower extremity youth hockey injuries. Keywords: youth hockey, body checking, injury prevention, femoroacetabular impingement, apophyseal avulsions
\end{abstract}

\section{Introduction}

Every day is a great day for hockey. - Mario Lemieux

Ice hockey is becoming one of the most popular sports played in North America. ${ }^{1,2}$ Already being the national sport in Canada, it continues to spread in the US as 358,000 players under the age of 18 were registered with the USA Hockey in 2014-2015. ${ }^{3}$ Youth ice hockey leagues start as young as 5 years of age. Female ice hockey participation in the US has also increased significantly, with a sevenfold increase in registrants since 1993..$^{2,3}$ At the international level, hockey is now played in 77 countries recognized by the International Ice Hockey Federation. ${ }^{4}$ However, despite the growth and popularity of the sport, there are ongoing concerns about the high injury rates associated with ice hockey participation. ${ }^{5}$ Injury rates are higher in games than in practice, ${ }^{1,6}$ and the risk of injury rises with increasingly higher level of play. ${ }^{7}$

Ice hockey is associated with numerous dangers as players can reach speeds $>25 \mathrm{mph}$ on a solid sheet of ice, surrounded by unyielding boards. ${ }^{8}$ They move a puck made of vulcanized rubber with a hockey stick made from wood or a composite. ${ }^{9,10}$ There are numerous collisions, many of them at high speeds. ${ }^{9}$ Body checking has been shown in numerous studies to be responsible for up to $45-86 \%$ of injuries in youth hockey. ${ }^{5,7,11,12}$ Clearly, there are intrinsic hazards of the game of ice hockey which cannot be completely eliminated. However, some recent injury prevention strategies are trying to lower the 
risk. The minimum age to allow body checking was raised from 11 to 13 years. ${ }^{2}$ In addition, stricter enforcement of rules by the officials (Fair Play Program [FPP]), appropriate standards for proper equipment and utility of education programs such as "Heads Up" and "Smart Hockey" have been implemented with success. With the rising popularity of ice hockey and its high injury rate, physicians will need to be more knowledgeable about the management and prevention of common injuries seen in young hockey players.

\section{Epidemiology}

Current estimates are that 13,000 hockey players of age 18 and younger will present to emergency departments in the US for injuries related to ice hockey. ${ }^{13}$ The annual incidence of injury increased to $163 \%$ in those aged 9-14 (Squirt, Pee Wee and Bantam) and 85\% among the 15- to 18-year-old group (Midgets, High School and Juniors) from 1990 to 2006 (Table 1). ${ }^{13}$ When comparing injury rates, numerous authors have reported a higher rate of injury with higher level of competition in ice hockey (Table 2). ${ }^{14-17}$ Furthermore, injuries are much more common in games or competition as opposed to practice ${ }^{6,15,18-20}$ with some studies reporting a 20-25 times greater chance of injury during a game than in practice. A recent epidemiological study reported injury rates in boys' high school hockey to be 23.2 per 10,000 athlete exposures. ${ }^{17}$ Ice hockey is second only to American football in rates of head injuries and fractures in high school athletes. ${ }^{21-23}$ Concussions and extremity contusions are the most common injuries encountered. ${ }^{7,17,24}$ Time lost from the ice can be significant in youth ice hockey, but the majority of injuries result in $<3$ weeks missed from activity. ${ }^{17}$

\section{Risk of injury from body checking}

There has been considerable controversy over the proper age at which to introduce checking into the sport of ice

Table I Current checking rules by level and age in the US and Canada

\begin{tabular}{lll}
\hline Category of player & $\begin{array}{l}\text { Age in years on December } \\
\mathbf{3} \text { Ist of playing season }\end{array}$ & $\begin{array}{l}\text { Checking } \\
\text { allowed }\end{array}$ \\
\hline $\begin{array}{l}\text { Mites (US); Novice } \\
\text { (Canada) }\end{array}$ & 7 and 8 & No \\
$\begin{array}{l}\text { Squirt (US); Atom } \\
\text { (Canada) }\end{array}$ & 9 and 10 & No \\
Pee Wee & 11 and 12 & No \\
Bantam & 13 and 14 & Yes \\
Midget & 15 and 16 & Yes \\
High School & $14-18$ & Yes \\
Juniors & 15 and older & Yes \\
College & $18-25$ & Yes \\
\hline
\end{tabular}

hockey. ${ }^{1,25,26}$ Recent rule changes have now raised the minimum age at which checking is permitted to the Bantam level (13-14 years old) (Table 1). The rationale to raise the age of checking to the Bantam level was that it would allow for further skill development and a decreased risk of injury. Several studies have demonstrated a clear increase of injury associated with body checking in youth hockey. ${ }^{5,7,27}$ Other studies have highlighted a threefold increase in concussion rates in youth leagues that allowed checking at the Pee Wee level compared to leagues that did not. ${ }^{5,28}$ Another study of nearly 1,000 Canadian youth hockey players of age 9-16 showed that $45 \%$ of all injuries were a result of body checking. ${ }^{7}$ Further foundation for the move came as a result of studies showing a significant reduction (2.5 times) of health care utilization costs in programs in which body checking was not allowed. ${ }^{29}$ The USA Hockey raised the age for checking to 13 (Bantam) in the 2011-2012 season, while Hockey Canada did not raise the age across all provinces until a body checking discussion meeting in $2014 .{ }^{30}$ The American Academy of Pediatrics still contends that the recommended age to permit body checking is 15 years but that the skill of checking can be taught in practice starting at 13 years of age. ${ }^{1}$

\section{Hip/pelvis}

The hip and groin constitute one of the most common areas to sustain an injury in ice hockey players. Approximately $9 \%$ of all reported injuries over a single season among pediatric youth ice hockey players involved the hip, thigh or groin, with the prevalence increasing with age and level of play. ${ }^{7}$ Injuries are often attributed to body checking; however, overuse injuries are becoming more predominant. ${ }^{15,31,32}$ Ayeni et $\mathrm{al}^{33}$ found that among pediatric and adolescent amateur ice hockey players, the most commonly reported hip injuries were muscle strains (50\%) and contusions (28.3\%) with noncontact injuries (40\%) accounting for the leading cause of reported injuries. The unique mechanical demands of ice hockey along with the speed and body contact inherent to the sport make the hip prone to specific soft tissue and intraarticular injuries.

\section{Adductor muscle strains}

Chronic groin pain is a common entity in ice hockey players and can often be due to a multitude of etiologies, making it difficult to diagnose and treat. The most common cause of chronic groin pain is an adductor muscle strain. ${ }^{34,35}$ Adductor muscle strains are an injury to the muscle-tendon unit causing pain on palpation of the adductor tendons or at their insertion on the pubic bone, with or without pain during resisted 
Table 2 Review of injury rates in youth ice hockey

\begin{tabular}{|c|c|c|c|c|c|c|}
\hline Study & Level of play & $\begin{array}{l}\text { Injury rates } \\
\text { practice/I,000 } \\
\text { player hours }\end{array}$ & $\begin{array}{l}\text { Injury rates } \\
\text { game/ I,000 player } \\
\text { hours }\end{array}$ & $\begin{array}{l}\text { Injury rates } \\
\text { practice/I,000 } \\
\text { athlete exposures }\end{array}$ & $\begin{array}{l}\text { Injury rates } \\
\text { game/I,000 } \\
\text { athlete exposures }\end{array}$ & $\begin{array}{l}\text { Injury rates } \\
\text { per } 100 \\
\text { players }\end{array}$ \\
\hline Stuart and Smith ${ }^{6}$ & Junior A (USA) & 3.9 & 96.1 & - & - & - \\
\hline \multirow[t]{3}{*}{ Stuart et al ${ }^{14}$} & Youth hockey & Squirt I.I & Squirt 1.0 & - & - & - \\
\hline & & Pee Wee 2.2 & Pee Wee 1.8 & - & - & - \\
\hline & & Bantam 2.5 & Bantam 4.3 & - & - & - \\
\hline Pinto et al ${ }^{18}$ & Junior A (USA) & 4 & 83 & - & - & - \\
\hline \multirow[t]{4}{*}{ McFaull|83 } & Youth hockey & - & - & - & - & Atom 3.54 \\
\hline & & & & & & PeeWee 6.6 \\
\hline & & & & & & Bantam 10.2 \\
\hline & & & & & & Midget 8.87 \\
\hline \multirow[t]{4}{*}{ Molsa et a ${ }^{84}$} & Youth hockey & - & - & - & Reported injuries & $<121.5$ \\
\hline & (UE injuries only) & & & & $\begin{array}{l}\text { per I,000 player } \\
\text { years }\end{array}$ & \\
\hline & & & & & & $12-149.4$ \\
\hline & & & & & & $15-1927.2$ \\
\hline \multirow{6}{*}{$\begin{array}{l}\text { Emery and } \\
\text { Meeuwisse }^{7}\end{array}$} & Youth hockey & Combined rate & 4.13 & - & - & 30.02 \\
\hline & (9-16 years) & practice and game & & & & \\
\hline & Atom & $\begin{array}{l}\text { Combined rate } \\
\text { practice and game }\end{array}$ & 1.12 & 0.54 & 1.57 & - \\
\hline & Pee Wee & $\begin{array}{l}\text { Combined rate } \\
\text { practice and game }\end{array}$ & 3.32 & 0.92 & 4.79 & - \\
\hline & Bantam & $\begin{array}{l}\text { Combined rate } \\
\text { practice and game }\end{array}$ & 4.16 & 0.98 & 6.22 & - \\
\hline & Midget & $\begin{array}{l}\text { Combined rate } \\
\text { practice and game }\end{array}$ & 6.07 & 1.77 & 8.97 & - \\
\hline \multirow[t]{2}{*}{ Hagel et a ${ }^{85}$} & Youth hockey & - & - & - & - & Atom 4.06 \\
\hline & & & & & & Pee Wee 8.55 \\
\hline Willer et al ${ }^{15}$ & Youth hockey & - & - & - & - & 1.96 \\
\hline \multirow[t]{4}{*}{ Decloe et al ${ }^{86}$} & $\begin{array}{l}\text { Female youth } \\
\text { hockey }\end{array}$ & Atom 1.0 & $\begin{array}{l}\text { Combined rate } \\
\text { practice and game }\end{array}$ & - & - & - \\
\hline & & Pee Wee I.5 & - & - & - & - \\
\hline & & Bantam I.0 & - & - & - & - \\
\hline & & Midget 1.9 & - & - & - & - \\
\hline Brooks and Loud' & $\begin{array}{l}\text { High school hockey, } \\
\text { USA }\end{array}$ & - & - & $2-2.6$ & - & - \\
\hline
\end{tabular}

Abbreviation: UE, upper extremity.

adduction. Adductor muscle strains commonly occur in ice hockey due to the strong eccentric contraction of adductor muscles during the skating motion. ${ }^{36}$ Proper treatment and rehabilitation can limit the amount of missed playing time and avoid surgical intervention. Restoring a balance between hip abductor and adductor strength with emphasis on strengthening the adductor muscle can also help to prevent these muscle strains in ice hockey players. ${ }^{35}$

\section{Apophyseal avulsion injuries}

The skeletal immaturity of adolescent athletes places them at an increased risk of sustaining apophyseal avulsion injuries, which are unique to the pediatric population. ${ }^{37}$ Apophyseal avulsion injuries commonly occur with indirect trauma that occurs with sudden forceful contraction of muscles. The pelvic and femoral apophyses remain cartilaginous later than other areas of the hip, and the inherent weakness of the open apophysis places them at an increased risk of avulsion injuries. ${ }^{38}$ Avulsion fractures can occur at the attachment site of major muscles, the most common being the anterior superior iliac spine (sartorius), anterior inferior iliac spine (Figure 1) (rectus femoris), lesser trochanter (iliopsoas) and the ischial tuberosity (hamstrings, adductor magnus). ${ }^{37}$ Treatment is often conservative with rest, ice and protected weight bearing with crutches; however, if there is significant osseous displacement, then surgical intervention can be considered. ${ }^{39}$ Operative intervention can be considered for displaced fractures $>2 \mathrm{~cm}$ on any view. Range of motion and stretching exercises can begin following rest and pain resolution. These injuries can require upward of 3 months to return to the ice. 


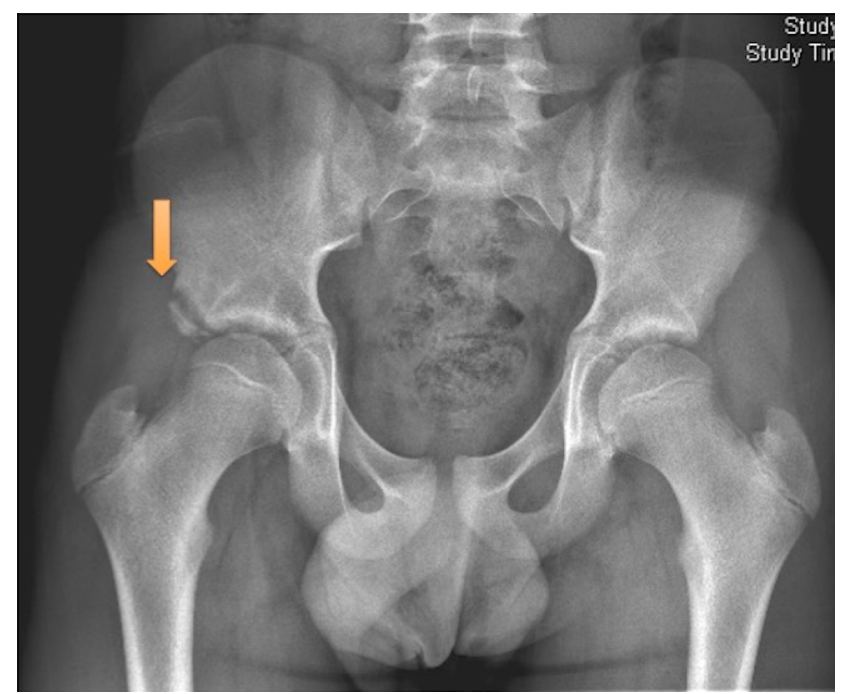

Figure I Anteroposterior radiograph of a right hip anterior inferior iliac spine avulsion (arrow) in a 12-year-old ice hockey player.

\section{Hip pointers}

Hip pointers are iliac crest contusions that occur due to the compression of gluteal muscles against the iliac crest after falling or being checked into the boards. Hip pointers are hematomas that present deep below the skin or in the abdominal muscles due to the compression of the gluteal muscles against the iliac crest. ${ }^{40}$ Patients can have significant pain with movements such as sneezing, coughing and running and are tender to palpation of the iliac crest. There is often concomitant swelling and/or bruising. ${ }^{41}$ These injuries are usually self-limited and resolve with time. Conservative management using the Rest, Ice, Compression and Elevation (RICE) protocol can help alleviate symptoms and minimize the hematoma. Rest and reducing weight bearing by using crutches are also recommended in order to allow proper healing. ${ }^{42}$ Plain radiographs can be used to rule out associated fractures.

\section{Athletic pubalgia/"hockey groin syndrome"}

Athletic pubalgia is another common cause of chronic groin pain in the adolescent and young adult skaters. It is caused by a tear or weakness of the posterior inguinal wall, characterized by pain that radiates to the adductor muscle and the groin region during sporting motions such as twisting or turning during a single-limb stance. ${ }^{35}$ The most common physical findings include the following: local tenderness over the pubic tubercle, conjoined tendon and mid-inguinal region; a tender, dilated superficial inguinal ring; tenderness of the posterior wall of the inguinal canal; and pain with a resisted sit-up at the inferolateral edge of the distal rectus abdominis. ${ }^{32,43}$ "Hockey groin syndrome" was described by
Irshad et $\mathrm{al}^{44}$ as another unique cause of groin pain in hockey players. It is characterized by the entrapment of ilioinguinal nerve branches in small tears of the external oblique aponeurosis. Pain often radiates to the hip, scrotum or back ${ }^{32}$ and worsens with the slap-shot motion and during the first few strides of skating.

The clinical diagnosis of athletic pubalgia and "hockey groin syndrome" is largely based on the exclusion of other causes of groin pain. Magnetic resonance imaging (MRI) can show a cleft sign at the rectus abdominis/adductor aponeurosis about the anterior pelvis; however, these are common findings in asymptomatic athletes. ${ }^{45}$ Most tests do not definitively confirm diagnosis, and physical exam findings can be subtle. ${ }^{46}$ Moderate-to-severe symptomatic athletic pubalgia is often refractory to nonoperative management and will typically require surgical repair for relief of symptoms. ${ }^{47}$ Surgical techniques are numerous and include open repair with or without mesh reinforcement, laproscopic repair with mesh and broad pelvic floor repair with possible adductor releases and neurectomies. In the case of hockey groin syndrome, groin exploration with ilioinguinal nerve ablation and reinforcement of the external oblique aponeurosis can be an effective treatment. ${ }^{44}$ Postoperative rehabilitation should focus on stepwise exercise progression with an emphasis on core and lower extremity strength, stability, flexibility and balance. Walking can begin early with progression to jogging by 3-4 weeks. Regardless of surgical approach, there is an $80-100 \%$ return-to-play rate, with athletes returning to sport within 6-8 weeks of surgery. ${ }^{43,48,49}$

\section{Femoroacetabular impingement (FAI)}

FAI is the most commonly diagnosed cause of hip and groin pain in ice hockey players at all ages and levels of play. ${ }^{32,33,50}$ Hockey players are predisposed to develop symptomatic FAI due to skating and hockey mechanics. Studies have shown that the hockey sprint start places the hip in two "at-risk" positions of abduction and external rotation during the initial push-off phase and flexion and internal rotation during the recovery phase at the end of the skating stride. ${ }^{50}$ Repeated subclinical physeal injury during the skating motion could predispose ice hockey players to increased alpha angles $\left(>55^{\circ}\right)$ and a greater risk of developing Cam-type impingement. ${ }^{51}$ This was found to be true not only in positional hockey players but also in goaltenders. Ross et $\mathrm{al}^{52}$ found that goaltenders with symptomatic FAI often had a Cam-type deformity characterized by an elevated alpha angle (Figure 2A) and loss of offset greater in magnitude and more lateral than positional players. This is attributed to the significant terminal 
A

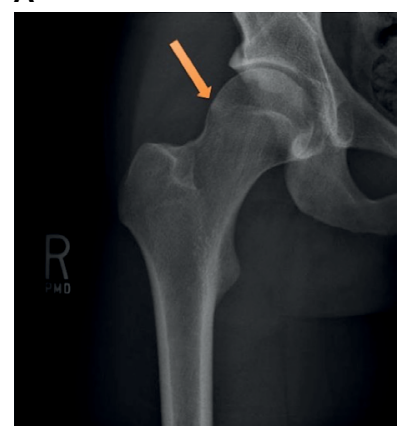

\section{B}

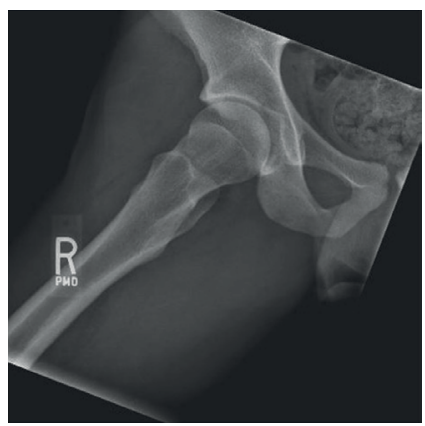

Figure 2 Radiographs of the right hip demonstrating a case of mixed Cam- and Pincer-type femoroacetabular impingement in a 17-year-old hockey goaltender. (A) The orange arrow points to the Cam bump in the AP radiograph. (B) Dunn view of the right hip.

Abbreviation: AP, anteroposterior.

hip range of motion required in the butterfly position and to make kick saves.

FAI is a major cause of hip pain, reduced range of motion during flexion and internal rotation and decreased performance in the athletic population. ${ }^{32}$ Pain is often described in the anterior hip or groin and can often be misdiagnosed as sports hernia or adductor strains, which are common secondary injuries due to FAI. ${ }^{53}$ The recurrent microtrauma and injury to the chondrolabral junction of the acetabulum due to Cam impingement, the most commonly diagnosed type in ice hockey players, also place the players at an increased risk of acetabular labral tears. Philippon et $\mathrm{al}^{51}$ identified labral tears in $93 \%$ of asymptomatic youth hockey players, particularly in hockey players with alpha angles $\geq 55^{\circ}$. Injuries to the acetabular labrum can be asymptomatic or present as mechanical symptoms, restricted range of motion and persistent hip pain. Physical examination with the flexion, adduction and internal rotation test, conventional radiographs including an anteroposterior (AP) and Dunn lateral radiograph (Figure 2A and $\mathrm{B}$ ) and MRI are the cornerstones in the diagnosis of FAI. If conservative management fails, arthroscopic resection of the Cam lesion and labral repair can be performed. ${ }^{40,54}$

\section{Knee}

\section{Medial collateral ligament injury/medial sided knee}

Injury to the medial collateral ligament (MCL) is common in youth and amateur hockey, despite being one of the strongest ligaments of the knee (Figure 3). ${ }^{55}$ The MCL is susceptible to injury as a result of an ice collision causing a valgus stress to the knee or from a player catching a skate on the ice with a twisting force. ${ }^{40}$ MCL injury can result in substantial time lost from the ice rink. ${ }^{9,55}$ There are three grades of injury to the MCL. Grade 1 injuries are mild sprains with a firm end

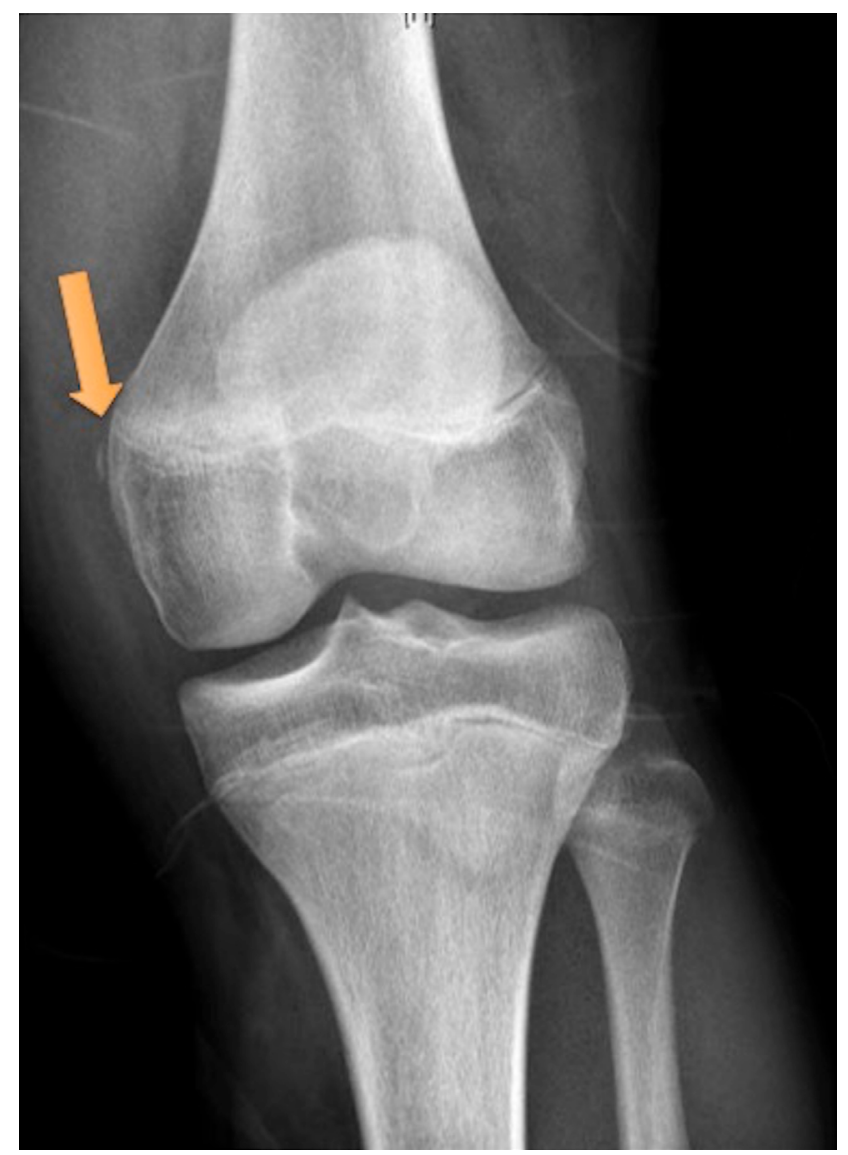

Figure 3 Plain radiograph of the right knee. A Bantam-level youth hockey player sustained a valgus force to the knee. This radiograph shows proximal medial collateral ligament injury with small osseous avulsion adjacent to the medial epicondyle (arrow).

point on valgus stress, Grade 2 injuries represent partial tearing of the MCL with $<1 \mathrm{~cm}$ of opening and Grade 3 injuries are associated with significant opening on stress without end point and are consistent with a complete tear. Initial treatment for the MCL involves the RICE protocol and a hinged knee brace. Once the pain and swelling are controlled, the players work through a rehabilitation program emphasizing the stationary bicycle, which has been shown to be beneficial for MCL healing. ${ }^{56}$ Return to the ice after MCL injury depends on the severity. To make the return to competition, the player must have regained motion and strength, stabilized on valgus stress of the knee and present with no knee swelling. Grade $3 \mathrm{MCL}$ injuries may take up to 8 weeks before the player get back to playing, whereas most players with Grade 2 injuries can return to competition before a month (3-4 weeks). Grade 1 injuries are milder, and most can return to the rink before 2 weeks. Skaters with a Grade $3 \mathrm{MCL}$ are recommended to wear a hinged knee brace or make a shin pad modification to help to prevent reinjury when they return to the ice. ${ }^{40}$

For the younger hockey players with open growth plates that sustain a valgus force to the outside of the knee, there 
should be consideration for a physeal fracture and not an MCL sprain. ${ }^{57}$ Stress radiographic views of the knee or an MRI may be necessary in these cases to correctly make the diagnosis. Treatment for a physeal fracture in this population is different from the MCL sprain. Casting or a hinged knee immobilizer locked in extension is often required until healing. This usually takes between 4 and 6 weeks depending on the severity. Rehabilitation working on regaining motion and strength is then initiated as the first step to get these players back.

\section{Foot/ankle}

\section{Skate bite}

"Skate bite" is a common ice hockey injury. It typically occurs at the start of a new hockey season in players with new or old skates. ${ }^{58}$ Skate bite is the result of the tongue part of the ice skate being too stiff. The rigid part of the skate tongue then presses against the anterior ankle of the young hockey player. Skating then causes inflammation of the tibialis anterior tendon, and the player will complain of pain and swelling along the anterior part of the ankle. ${ }^{42}$ Treatment for skate bite consists of placing a piece of foam or padding between the skate tongue and the anterior ankle. Nonsteroidal anti-inflammatory drug (NSAID) gel (diclofenac topical 1\% gel) and ice can also be applied to the anterior ankle to help with the inflammation. Breaking in the skate by flexing the stiff tongue back and forth can also be helpful. Skate bite can be avoided by educating the players to work on the flexibility of their skate tongue before the start of the season.

\section{High ankle sprain/syndesmotic injury}

Another injury frequently seen in ice hockey players is the syndesmotic injury or high ankle sprain ${ }^{9}$ that occurs as a result of the constraint of the ice skate. ${ }^{32} \mathrm{~A}$ syndesmotic ankle injury can occur as a result of the high speed attained on the ice with the rapid change of direction, usually with an external rotation-type force. There is some evidence that syndesmotic injuries may make up a higher percentage of ankle ligament injuries in hockey players. ${ }^{59}$ On exam, the player will have a positive syndesmotic squeeze test and may have difficulty with weight bearing. It is important to distinguish a high ankle injury as it can be associated with significant time lost from sport, as opposed to a low ankle sprain which rarely results in loss of ice time for hockey players. ${ }^{59}$ The stiff ice skate may be protective for low ankle sprains but places the region just above the boot at risk for injury. Treatment depends on severity of the injury, but in the pediatric and adolescent athlete, the injury can usually be managed conservatively with immobilization, ice and physical therapy.

\section{Boot top lacerations}

A sharp skate blade can also cut an opposing player's leg right above the top of the skate. This is called a "boot top laceration" and can cause serious injury to the tendons and neurovascular structures in the lower leg from a seemingly innocuous and small skin laceration. ${ }^{60}$ With any laceration of a player, a thorough neurovascular examination should be performed as misdiagnosis with this injury is not unusual. Players endanger themselves by turning the skate tongue downward, which can expose more of the lower leg. Kevlar socks can also be helpful in preventing this type of injury. ${ }^{61}$

\section{Injury prevention}

Several injury prevention initiatives have been implemented over the years in youth ice hockey with mixed results. While not the focus of this review, head and neck injuries comprise between 20 and $30 \%$ of reported youth ice hockey injuries. ${ }^{22,62}$ Mandatory use of face masks with helmets has been a passive prevention that has dramatically reduced the number of facial and eye injuries. ${ }^{63-65}$ Research on the cause of neck and spinal cord injuries in hockey identified pushing or checking a player from behind head first into the boards as a major cause. ${ }^{66}$ As a result, Hockey Canada implemented a major penalty for checking from behind (CFB) in the $1985-1986$ season. ${ }^{67}$ As a result of this rule and change and education programs aimed at increasing awareness of the dangers of CFB, the annual incidence of spinal cord injury is down but has not been eliminated. ${ }^{67}$ Despite a decline in severe spinal cord injuries, the overall number of head and neck injuries in ice hockey remains very high, and additional interventions are necessary. ${ }^{68}$ A recent summit on ice hockey injuries recommended a zero tolerance policy on hits to the head and fighting in a new action plan to help to reduce injury and sport-related concussion. ${ }^{69}$ The following section will review some of the current safety strategies in youth ice hockey.

\section{Proper equipment (helmet fit/wear)}

Youth ice hockey players wear equipment from head to toe (the helmet down to their skates) when playing. There is a lack of literature verifying the merit of most ice hockey equipment; however, the speed of the puck, the use of a composite or wooden stick, the hard ice surface and rigid boards support the continued use of hockey equipment to protect from injury. ${ }^{1}$ 


\section{Education programs and behavioral modification}

Education programs have been implemented as an injury prevention tool in youth hockey in both the US and Canada. ${ }^{68,70}$ The first of these aimed to educate on the dangers of CFB. ${ }^{68}$ Examples of these programs included the USA Hockey's "Heads Up Hockey", Massachusetts Medical Society's "Heads up, Don't Duck" and "Smart Hockey with Mike Bossy" from ThinkFirst Canada ${ }^{69}$ More novel approaches have even included using video games to embed educational content about the dangers of concussion in hockey. ${ }^{71}$ Public perception is that these educational programs can be helpful to reduce injury in ice hockey, however the actual evidence to support the efficacy of these programs is not particularly robust. ${ }^{72}$ A recent article reviewed the effectiveness of the "Smart Hockey: More Safety, More Fun" on knowledge transfer about the dangers of concussion and found an immediate improvement in concussion knowledge, but the effect was lost at the 2-month follow-up. ${ }^{72}$ This article supports the findings of a systematic review that failed to find definitive evidence that educational programs were effective in preventing injury. ${ }^{73}$ More work needs to be done to show that these educational interventions can be effective in lowering injury rates and in increasing knowledge retention in young hockey players.

\section{Rule changes}

The FPP was originally created based on the experimental work of Vaz and has good potential to reward positive behavior and penalize dangerous unsportsmanlike conduct and behavior. ${ }^{74}$ The FPP awards points to teams that display good sportsmanship and stay below a preset number of penalties in a game. ${ }^{75}$ Results of the FPP have been mostly positive and encouraging. A study of FPP in Quebec youth hockey showed a significant reduction in penalties after implementation compared to youth leagues that did not follow FPP rules. ${ }^{76}$ Use of FPP in a youth hockey tournament setting showed a reduction in penalty minutes, severe penalties and injury rate. ${ }^{70}$ In Minnesota, introduction of FPP and implementation of no checking at the Pee Wee level resulted in a drop from 28 CFB penalties per 100 games to three per 100 games and hits to the head from 12 per 100 games to less than one per 100 games. ${ }^{69}$

In Minnesota youth hockey, FPP is one of three components of the Hockey Education Program (HEP) that aimed to enhance skill development and sportsmanship and develop a fair play approach to the game of hockey. ${ }^{75} \mathrm{HEP}$ was launched in 2004 in direct response to the death of a youth hockey coach in a fight with a parent. The program showed a decline in penalties and an increase in fair play points achieved by teams during the four seasons studied. ${ }^{75}$

Arguments against FPP point out that it may encourage teams to think they have an acceptable quota of penalties that they are entitled to in a game and that officials may limit penalties called in important or high-stakes games. ${ }^{73}$ Furthermore, more work on the effect of FPP on reducing injuries, major penalties, CFB and hits to the head needs to be investigated.

\section{Ice rink size}

In the early days of ice hockey, the game was played outdoors, and wooden barriers were used to keep the puck in play. ${ }^{77}$ As the game evolved and turned into a spectator sport, hockey transitioned to an indoor sport played in ice rinks. The size of the ice hockey rink surface can vary: international $(61 \mathrm{~m} \times 30.5 \mathrm{~m})$, intermediate $(61 \mathrm{~m} \times 28.7 \mathrm{~m})$ and North American $(61 \mathrm{~m} \times 26 \mathrm{~m}) \cdot{ }^{78}$ Studies of the Canadian Junior Hockey League and another from the World Junior Championships have highlighted the inverse relationship between ice hockey rink size and collision rates and injuries per game..$^{78,79}$ Presumably, players are getting bigger and faster, and increasing the ice surface can reduce injury rates by decreasing contact between the players. With the growing concern for concussions in youth ice hockey, some have advocated for playing the game on more international $(61 \mathrm{~m} \times 30.5 \mathrm{~m})$ sheets of ice. ${ }^{19}$

\section{Referees}

Referees are responsible for enforcing the rules and are essential to promoting an environment of fair play. The Ice Hockey Summit on Concussion called for a zero tolerance policy with regard to hits to the head whether intentional or incidental. ${ }^{80}$ "Loose officiating" or not enforcing the rules for safe play has been postulated as a cause of increased injuries. ${ }^{81}$ A survey study of referees in Ontario revealed that $90 \%$ of referees have been the recipients of anger and aggression and $>50 \%$ have been involved in a game where they felt they lost control of the game, promoting an aggressive style of play they felt was responsible for injury. This study highlights the importance of support for the referees and rigorous enforcement of infractions for all participants of both teams to promote fair play on the ice. ${ }^{82}$

\section{Conclusion}

Ice hockey is an exciting, fast-paced game with a high injury rate. Physicians taking care of youth hockey players should be familiar with the common lower extremity musculoskeletal 
injury patterns that result from play. FPPs and enforcement of the rules by officials can make the game safer to play and discourage CFB and other aggressive acts on ice which can increase injury. Increasing the size of the ice surface to international size may also help to reduce injuries on the ice. The goal is to ensure that our young hockey players heading to the ice rink have fun, improve their skillset and develop a desire and passion to make playing ice hockey a lifelong recreational activity.

\section{Author contributions}

All authors equally contributed to this paper in the conception and design of the study, literature review and analysis, drafting and revising it critically and all authors approved the final version to be published.

\section{Disclosure}

Brian Schulz is a team physician for the Anaheim Ducks, a professional ice hockey team based in Anaheim, CA, USA. The authors report no other conflicts of interest in this work.

\section{References}

1. Brooks A, Loud KJ; Council on Sports Medicine and Fitness. Reducing injury risk from body checking in boys' youth ice hockey. Pediatrics. 2014;133(6):1151-1157.

2. Polites SF, Sebastian AS, Habermann EB, Iqbal CW, Stuart MJ, Ishitani MB. Youth ice hockey injuries over 16 years at a pediatric trauma center. Pediatrics. 2014;133(6):e1601-e1607.

3. Vartiainen MV, Holm A, Peltonen K, Luoto TM, Iverson GL, Hokkanen L. King-Devick test normative reference values for professional male ice hockey players. Scand J Med Sci Sports. 2015;25(3):e327-e330.

4. International Ice Hockey Federation (IIHF). IIHF Member National Associations. 2016. Available from: http://www.iihf.com/iihf-home/ the-iihf/members. Accessed July 28, 2016.

5. Emery CA, Kang J, Shrier I, et al. Risk of injury associated with body checking among youth ice hockey players. JAMA. 2010;303(22): 2265-2272.

6. Stuart MJ, Smith A. Injuries in Junior A ice hockey. A three-year prospective study. Am J Sports Med. 1995;23(4):458-461.

7. Emery CA, Meeuwisse WH. Injury rates, risk factors, and mechanisms of injury in minor hockey. Am J Sports Med. 2006;34(12):1960-1969.

8. Molsa J, Airaksinen O, Nasman O, Torstila I. Ice hockey injuries in Finland. A prospective epidemiologic study. Am J Sports Med. 1997;25(4):495-499.

9. Flik K, Lyman S, Marx RG. American collegiate men's ice hockey: an analysis of injuries. Am J Sports Med. 2005;33(2):183-187.

10. Laliberte DJ. Biomechanics of ice hockey slap shots: which stick is best? Sport J. 2009;12(1):1.

11. Marchie A, Cusimano MD. Bodychecking and concussions in ice hockey: should our youth pay the price? CMAJ. 2003;169(2):124-128.

12. Brust JD, Leonard BJ, Pheley A, Roberts WO. Children's ice hockey injuries. Am J Dis Child. 1992;146(6):741-747.

13. Deits J, Yard EE, Collins CL, Fields SK, Comstock RD. Patients with ice hockey injuries presenting to US emergency departments, 1990-2006. J Athl Train. 2010;45(5):467-474.

14. Stuart MJ, Smith AM, Nieva JJ, Rock MG. Injuries in youth ice hockey: a pilot surveillance strategy. Mayo Clin Proc. 1995;70(4):350-356.
15. Willer B, Kroetsch B, Darling S, Hutson A, Leddy J. Injury rates in house league, select, and representative youth ice hockey. Med Sci Sports Exerc. 2005;37(10):1658-1663.

16. MacCormick L, Best TM, Flanigan DC. Are there differences in ice hockey injuries between sexes?: a systematic review. Orthop J Sports Med. 2014;2(1):2325967113518181.

17. Matic GT, Sommerfeldt MF, Best TM, Collins CL, Comstock RD, Flanigan DC. Ice hockey injuries among United States high school athletes from 2008/2009-2012/2013. Phys Sportsmed. 2015;43(2):119-125.

18. Pinto M, Kuhn JE, Greenfield ML, Hawkins RJ. Prospective analysis of ice hockey injuries at the Junior A level over the course of one season. Clin J Sport Med. 1999;9(2):70-74.

19. Benson BW, Meeuwisse WH. Ice hockey injuries. Med Sport Sci. 2005;49:86-119.

20. Agel J, Harvey EJ. A 7-year review of men's and women's ice hockey injuries in the NCAA. Can J Surg. 2010;53(5):319-323.

21. Swenson DM, Henke NM, Collins CL, Fields SK, Comstock RD. Epidemiology of United States high school sports-related fractures, 2008-09 to 2010-11. Am J Sports Med. 2012;40(9):2078-2084.

22. Marar M, McIlvain NM, Fields SK, Comstock RD. Epidemiology of concussions among United States high school athletes in 20 sports. Am J Sports Med. 2012;40(4):747-755.

23. Swenson DM, Yard EE, Collins CL, Fields SK, Comstock RD. Epidemiology of US high school sports-related fractures, 2005-2009. Clin J Sport Med. 2010;20(4):293-299.

24. Roberts WO, Brust JD, Leonard B. Youth ice hockey tournament injuries: rates and patterns compared to season play. Med Sci Sports Exerc. 1999;31(1):46-51.

25. Warsh JM, Constantin SA, Howard A, Macpherson A. A systematic review of the association between body checking and injury in youth ice hockey. Clin J Sport Med. 2009;19(2):134-144.

26. Kukaswadia A, Warsh J, Mihalik JP, Pickett W. Effects of changing body-checking rules on rates of injury in minor hockey. Pediatrics. 2010;125(4):735-741.

27. Macpherson A, Rothman L, Howard A. Body-checking rules and childhood injuries in ice hockey. Pediatrics. 2006;117(2):e143-e147.

28. Black AM, Macpherson AK, Hagel BE, et al. Policy change eliminating body checking in non-elite ice hockey leads to a threefold reduction in injury and concussion risk in 11- and 12-year-old players. Br J Sports Med. 2016;50(1):55-61.

29. Lacny S, Marshall DA, Currie G, et al. Reality check: the cost-effectiveness of removing body checking from youth ice hockey. BrJ Sports Med. 2014;48(17):1299-1305.

30. McKay CD, Meeuwisse WH, Emery CA. Informing body checking policy in youth ice hockey in Canada: a discussion meeting with researchers and community stakeholders. Can J Public Health. 2014;105(6):e445-e449.

31. Brenner JS; American Academy of Pediatrics Council on Sports Medicine and Fitness. Overuse injuries, overtraining, and burnout in child and adolescent athletes. Pediatrics. 2007;119(6):1242-1245.

32. Shindle MK, Marx RG, Kelly BT, Bisson L, Burke CJ 3rd. Hockey injuries: a pediatric sport update. Curr Opin Pediatr. 2010;22(1):54-60.

33. Ayeni OR, Kowalczuk M, Farag J, et al. Trends in reporting of mechanisms and incidence of hip injuries in males playing minor ice hockey in Canada: a cross-sectional study. Open Access J Sports Med. 2014;5:143-149.

34. Morelli V, Smith V. Groin injuries in athletes. Am Fam Physician. 2001; 64(8):1405-1414.

35. Tyler TF, Silvers HJ, Gerhardt MB, Nicholas SJ. Groin injuries in sports medicine. Sports Health. 2010;2(3):231-236.

36. Chang R, Turcotte R, Pearsall D. Hip adductor muscle function in forward skating. Sports Biomech. 2009;8(3):212-222.

37. Smith DV, Bernhardt DT. Hip injuries in young athletes. Curr Sports Med Rep. 2010;9(5):278-283.

38. Kocher MS, Tucker R. Pediatric athlete hip disorders. Clin Sports Med. 2006;25(2):241-253, viii.

39. Anderson K, Strickland SM, Warren R. Hip and groin injuries in athletes. Am J Sports Med. 2001;29(4):521-533. 
40. Laprade RF, Surowiec RK, Sochanska AN, et al. Epidemiology, identification, treatment and return to play of musculoskeletal-based ice hockey injuries. Br J Sports Med. 2014;48(1):4-10.

41. Waite BL, Krabak BJ. Examination and treatment of pediatric injuries of the hip and pelvis. Phys Med Rehabil Clin NAm. 2008;19(2):305-318, ix.

42. LaPrade RF, Wijdicks CA, Griffith CJ. Division I intercollegiate ice hockey team coverage. Br J Sports Med. 2009;43(13):1000-1005.

43. Meyers WC, McKechnie A, Philippon MJ, Horner MA, Zoga AC, Devon ON. Experience with "sports hernia” spanning two decades. Ann Surg. 2008;248(4):656-665.

44. Irshad K, Feldman LS, Lavoie C, Lacroix VJ, Mulder DS, Brown RA. Operative management of "hockey groin syndrome": 12 years of experience in National Hockey League players. Surgery. 2001;130(4):759764; discussion 764-766.

45. Zoga AC, Kavanagh EC, Omar IM, et al. Athletic pubalgia and the "sports hernia”: MR imaging findings. Radiology. 2008;247(3):797-807.

46. Lynch SA, Renstrom PA. Groin injuries in sport: treatment strategies. Sports Med. 1999;28(2):137-144.

47. LeBlanc KE, LeBlanc KA. Groin pain in athletes. Hernia. 2003;7(2):68-71.

48. Jakoi A, O’Neill C, Damsgaard C, Fehring K, Tom J. Sports hernia in National Hockey League players: does surgery affect performance? Am J Sports Med. 2013;41(1):107-110.

49. Muschaweck U, Berger LM. Sportsmen's groin-diagnostic approach and treatment with the minimal repair technique: a single-center uncontrolled clinical review. Sports Health. 2010;2(3):216-221.

50. Stull JD, Philippon MJ, LaPrade RF. “At-risk" positioning and hip biomechanics of the Peewee ice hockey sprint start. Am J Sports Med. 2011;39 Suppl:29S-35S.

51. Philippon MJ, Ho CP, Briggs KK, Stull J, LaPrade RF. Prevalence of increased alpha angles as a measure of cam-type femoroacetabular impingement in youth ice hockey players. Am J Sports Med. 2013;41(6):1357-1362.

52. Ross JR, Bedi A, Stone RM, Sibilsky Enselman E, Kelly BT, Larson CM. Characterization of symptomatic hip impingement in butterfly ice hockey goalies. Arthroscopy. 2015;31(4):635-642.

53. Anderson SE, Siebenrock KA, Tannast M. Femoroacetabular impingement. Eur J Radiol. 2012;81(12):3740-3744.

54. Fabricant PD, Heyworth BE, Kelly BT. Hip arthroscopy improves symptoms associated with FAI in selected adolescent athletes. Clin Orthop Relat Res. 2012;470(1):261-269.

55. Grant JA, Bedi A, Kurz J, Bancroft R, Miller BS. Incidence and injury characteristics of medial collateral ligament injuries in male collegiate ice hockey players. Sports Health. 2013;5(3):270-272.

56. Woo SL, Gomez MA, Sites TJ, Newton PO, Orlando CA, Akeson WH. The biomechanical and morphological changes in the medial collateral ligament of the rabbit after immobilization and remobilization. J Bone Joint Surg Am. 1987;69(8):1200-1211.

57. Veenema KR. Valgus knee instability in an adolescent: ligament sprain or physeal fracture? Phys Sportsmed. 1999;27(8):62-75.

58. Tlougan BE, Mancini AJ, Mandell JA, Cohen DE, Sanchez MR. Skin conditions in figure skaters, ice-hockey players and speed skaters: part II - cold-induced, infectious and inflammatory dermatoses. Sports Med. 2011;41(11):967-984.

59. Wright RW, Barile RJ, Surprenant DA, Matava MJ. Ankle syndesmosis sprains in national hockey league players. Am J Sports Med. 2004; 32(8):1941-1945.

60. Simonet WT, Sim L. Boot-top tendon lacerations in ice hockey. JTrauma. 1995;38(1):30-31.

61. Nauth A, Aziz M, Tsuji M, Whelan DB, Theodoropoulos JS, Zdero R. The protective effect of Kevlar socks against hockey skate blade injuries: a biomechanical study. Orthop J Sports Med. 2014;2 Suppl:2325967114S00109.

62. Moslener MD, Wadsworth LT. Ice hockey: a team physician's perspective. Curr Sports Med Rep. 2010;9(3):134-138.

63. Benson BW, Mohtadi NG, Rose MS, Meeuwisse WH. Head and neck injuries among ice hockey players wearing full face shields vs half face shields. JAMA. 1999;282(24):2328-2332.
64. Stuart MJ, Smith AM, Malo-Ortiguera SA, Fischer TL, Larson DR. A comparison of facial protection and the incidence of head, neck, and facial injuries in Junior A hockey players. A function of individual playing time. Am J Sports Med. 2002;30(1):39-44.

65. Pashby TJ. Eye injuries in Canadian sports and recreational activities. Can J Ophthalmol. 1992;27(5):226-229.

66. Tator CH, Edmonds VE, Lapczak L, Tator IB. Spinal injuries in ice hockey players, 1966-1987. Can J Surg. 1991;34(1):63-69.

67. Tator CH, Provvidenza C, Cassidy JD. Update and overview of spinal injuries in Canadian ice hockey, 1943 to 2011: the continuing need for injury prevention and education. Clin J Sport Med. 2016;26(3):232-238.

68. Cook DJ, Cusimano MD, Tator CH, Chipman ML. Evaluation of the ThinkFirst Canada, Smart Hockey, brain and spinal cord injury prevention video. Inj Prev. 2003;9(4):361-366.

69. Smith AM, Stuart MJ, Dodick DW, et al. Ice Hockey Summit II: zero tolerance for head hits and fighting. Curr Sports Med Rep. 2015;14(2):135-144.

70. Roberts WO, Brust JD, Leonard B, Hebert BJ. Fair-play rules and injury reduction in ice hockey. Arch Pediatr Adolesc Med. 1996;150(2): $140-145$.

71. Goodman D, Bradley NL, Paras B, Williamson IJ, Bizzochi J. Video gaming promotes concussion knowledge acquisition in youth hockey players. J Adolesc. 2006;29(3):351-360.

72. Cusimano MD, Chipman M, Donnelly P, Hutchison MG. Effectiveness of an educational video on concussion knowledge in minor league hockey players: a cluster randomised controlled trial. Br J Sports Med. 2014;48(2):141-146.

73. Cusimano MD, Nastis S, Zuccaro L. Effectiveness of interventions to reduce aggression and injuries among ice hockey players: a systematic review. CMAJ. 2013;185(1):E57-E69.

74. Vaz E. The Professionalization of Young Hockey Players. Lincoln, NE: University of Nebraska Press; 1982.

75. Smith AM, Jorgenson M, Sorenson MC, et al. Hockey Education Program (HEP): a statewide measure of fair play, skill development, and coaching excellence. J ASTM Int. 2009;6(4):1-14.

76. Brunelle JP, Goulet C, Arguin H. Promoting respect for the rules and injury prevention in ice hockey: evaluation of the fair-play program. $J$ Sci Med Sport. 2005;8(3):294-304.

77. Vaughan G. Hurley to Hockey. In: The Puck Starts Here. The Origin of Canada's Great Winter Game Ice Hockey. Fredericton: Goose Lane Editions; 1996.

78. Wennberg R. Effect of ice surface size on collision rates and head impacts at the World Junior Hockey Championships, 2002 to 2004. Clin J Sport Med. 2005;15(2):67-72.

79. Watson RC, Nystrom MA, Buckolz E. Safety in Canadian junior ice hockey: the association between ice surface size and injuries and aggressive penalties in the Ontario Hockey League. Clin J Sport Med. 1997; 7(3):192-195.

80. Smith AM, Stuart MJ, Greenwald RM, et al. Proceedings from the ice hockey summit on concussion: a call to action. Clin J Sport Med. 2011; 21(4):281-287.

81. Reynen PD, Clancy WG Jr. Cervical spine injury, hockey helmets, and face masks. Am J Sports Med. 1994;22(2):167-170.

82. Ackery AD, Tator $\mathrm{CH}$, Snider C. Violence in Canadian amateur hockey: the experience of referees in Ontario. Clin J Sport Med. 2012;22(2):86-90.

83. McFaull S. Contact injuries in minor hockey: a review of the CHIRPP database for the 1998/1999 hockey season. Canadian Hospitals Injury Reporting and Prevention Program (CHIRPP) News. Ottawa Health Canada. 2001;(19):1-9.

84. Molsa J, Kujala U, Myllynen P, Torstila I, Airaksinen O. Injuries to the upper extremity in ice hockey: analysis of a series of 760 injuries. $\mathrm{Am}$ J Sports Med. 2003;31(5):751-757.

85. Hagel BE, Marko J, Dryden D, Couperthwaite AB, Sommerfeldt J, Rowe $\mathrm{BH}$. Effect of bodychecking on injury rates among minor ice hockey players. CMAJ. 2006;175(2):155-160.

86. Decloe MD, Meeuwisse WH, Hagel BE, Emery CA. Injury rates, types, mechanisms and risk factors in female youth ice hockey. Br J Sports Med. 2014;48(1):51-56. 


\section{Publish your work in this journal}

The Open Access Journal of Sports Medicine is an international, peer-reviewed, open access journal publishing original research, reports, reviews and commentaries on all areas of sports medicine. The journal is included on PubMed. The manuscript management system is completely online and includes a very quick and fair

Submit your manuscript here: http://www.dovepress.com/open-access-journal-of-sports-medicine-journal

peer-review system. Visit http://www.dovepress.com/testimonials.php to read real quotes from published authors. 